\title{
Knowledge of and Compliance with Standard Precautions among Student Nurses
}

\author{
Leodoro J. Labrague, Rheajane A. Rosales, Maricel M. Tizon \\ College of Nursing, Samar State University, Philippines \\ E-mail: Leo7_ci@yahoo.com \\ College of Nursing, Samar State University, Philippines \\ E-mail: hea_rn@yahoo.com \\ College of Nursing, Samar State University, Philippines \\ E-mail: maricel_mabulac@yahoo.com
}

\begin{abstract}
Student nurses are often exposed to various infections during their clinical education. Knowledge and compliance with standard precautions is essential to prevent hospital associated infections and protect patients as well as medical workers from exposure to infectious agents. This study assessed the knowledge and degree of compliance regarding standard precautions among student nurses in a government university in Samar, Philippines. A cross-sectional study was adopted for this investigation and data were collected over a period of one month from April 8 to May 7, 2012. Fifty eight student nurses who were enrolled in the university were asked to complete the self report questionnaires regarding standard precautions. Vast majority (89.7\%) of the student nurses have good knowledge (students are satisfactorily well versed with the concepts of standard precautions) $(\mathrm{m}=14.45 / 19)$ and high compliance $(\mathrm{m}=3.59)$ of standard precautions. The use of mask has the highest degree of compliance $(m=3.95)$ while the use of eye goggles has the lowest degree of compliance $(\mathrm{m}=3.19)$. Findings suggest no significant association between knowledge and compliance with standard precautions. Teaching approaches must be geared towards intensifying further the compliances especially with the use of other protective equipments such eye goggles and gloves. Furthermore, environment that models and promotes standard precaution practices should be developed by the faculty.
\end{abstract}

Keywords: Standard precautions, compliance, knowledge, hospital acquired infection 


\section{Introduction}

Health care professionals are constantly exposed to microorganisms. Many of which can cause serious or even lethal infections [1]. Nurses in particular are often exposed to various infections during the course of carrying out their nursing activities [2]. Nursing students are also at risk of such infections and injuries due to accidental contamination during their practical occupational exposure. Exposure to infectious material can be minimized by adherence to standard precautions which are designed to reduce the risk of acquiring occupational infection from both known and unexpected sources in the healthcare setting [3]. The Center for Disease Control and Prevention (CDC) in 1996, introduced a revised version of a preventive concept against nosocomial infections that originated in the 1960s. It advocates basic standard precautions for all healthcare delivery and additional specific measures to protect healthcare workers and patients from exposure to potentially harmful microorganisms [4]. Standard Precautions include: hand hygiene, use of personal protective equipment (e.g., gloves, gowns, masks), safe injection practices, safe handling of potentially contaminated equipment or surfaces in the patient environment, and respiratory hygiene/cough etiquette [5].

As the incidence of Hospital Acquired Infections (HAIs) has increased globally [6], emphasis on strict implementation of standard precautions among health care settings has been carried out. Standard precautions have been shown to effectively reduce occupational hazards. Compliance on the part of healthcare workers with standard precautions has been recognized as an efficient and effective means to prevent and control health care-associated infections in patients and health workers $[3,7]$.

Despite the guidelines developed in several countries, compliance with aseptic precautions is known to be "poor and lacking" [8-11]. Several studies suggest indicated that better knowledge of universal precautions among health care workers was one of the predictors of better compliance [12-15,23]. Other reported factors that contribute to non-compliance with standard precautions include lack of understanding and knowledge among health care workers on how to properly use protective barriers [16], lack of time [17], lack of resources, [18] and lack of proper training [19-21].

Studies on standard precautions are increasing over the world [3,7,8,11-32], however there has been limited attention paid to investigating nursing students' understanding and compliance regarding standard precautions within certain localities. Hence this study was conducted.

\section{Research Objective}

This investigation assessed the knowledge and degree of compliance regarding standard precautions among student nurses in a government university in Samar, Philippines. 


\section{Methodology}

\section{Design}

A cross-sectional study was adopted for this investigation. Cross-sectional studies involve a single examination like a snapshot of a cross-section of a population at a given time. This study design is appropriate because the main objective of this investigation was to assess a certain group of nursing students' understanding and compliance of standard precautions.

\section{Participants}

Data were collected over a period of one month from April 8 to May 7, 2012. Fifty eight student nurses who were enrolled in the said university were all provided the opportunity to be participants in the investigation. Participants had to be currently enrolled in the university and presently in their $3^{\text {rd }}$ and $4^{\text {th }}$ year in the nursing program, and had to be willing to fully participate in the investigation.

\section{Instrumentation}

To gather data, the investigators utilized the questionnaires developed by Tavolacci et al. [22]. Questions were based on the basic concepts, content, and activity requirements of the standard precautions, covering 19 items, with possible responses of 'yes' and 'no'. 'Yes' is given a value of 1 point, and 'no' with 0 points; the maximum possible score is 19 . The higher the score, the greater the assumed knowledge about standard precautions the participant has. Result of test was interpreted as follows; $16-19$ as "Very Good Knowledge", $12-15$ as "Good Knowledge", 8 - 11 as "Fair Knowledge", and 0 - 7 as "Poor Knowledge".

The questionnaire was further reviewed by experts in infection control to ensure quality and content validity. The questionnaire was validated for its reliability resulting in statistical value of 0.92 (Cronbach's alpha).

Compliance with standard precautions was measured using the standard precautions questionnaires developed by Luo et al. [23] One item on compliance questionnaire was removed, since students are not yet allowed to perform venous puncture. The compliance questionnaire was validated for its reliability resulting in statistical value of 0.90 (Cronbach's alpha). There are 17 compliance items with a scale of $0-4$ points: $0=$ never, $1=$ seldom, $2=$ sometimes, $3=$ usually, and $4=$ always, giving a score range of 0-68. In determining the level of compliance, the following scaling was used; for High Compliance $=3.51-4.00$, Average Compliance $=2.51-3.50$, Low Compliance $=1.51-2.50$ and Very Low Compliance $=0-1.50$. The higher the mean score, the better that person carries out the standard precautions.

Both the knowledge questionnaire and the compliance check list were drafted in a structured format and they were used in a pilot test before being distributed to the respondents enrolled in this investigation. Refinement and modifications were done on the basis of pretest results. Furthermore, questionnaires were validated through expert validation by five experts in the field of infection. The 
questionnaires were handed out by the investigators at the site personally, and collected on the spot once they had been completed individually and anonymously by the student-respondents.

\section{Ethical considerations}

The study protocol was reviewed and approved by the Health Ethics Committee of Samar State University, Philippines. All the participants were fully informed about the purpose of the study. Confidentiality and anonymity of the respondents were maintained by only a code number on the questionnaire.

\section{Data Analysis}

The data from the questionnaire were coded and entered into a computerized data base and analyzed using SPSS, version 16. Frequencies, percentages, mean and median were used for analyzing the selected socio- demographic data and assessing level of knowledge and degree of compliance of student nurses. Pearson's correlation coefficient was utilized to test the relationship between the knowledge and compliance with standard precautions. A p-value of equal to or less than 0.05 was considered statistically significant.

\section{Results}

There were 58 respondents in the study. There were 10 (17.2\%) male and 48 $(82.8 \%)$ female respondents. Majority of the respondents or $53(91.4 \%)$ were within the age bracket of 21 to 23 years old with mean age of 21.5 years. Almost all of the respondents $56(96.6 \%)$ were single while only $2(3.5 \%)$ were married. (Table 1)

Table 1: Participant Demographics

\begin{tabular}{|l|c|c|c|}
\hline \multicolumn{1}{|c|}{ Variable } & & $\mathrm{n}$ & Percentage (\%) \\
\hline Age & & 58 & 100 \\
\hline & $21-23$ & 53 & 91.38 \\
\hline Gender & $17-20$ & 5 & 8.62 \\
\hline & Female & 48 & 82.76 \\
\hline Marital Status & Male & 10 & 17.24 \\
\hline & Single & 56 & 96.55 \\
\hline & Married & 2 & 3.45 \\
\hline
\end{tabular}

Table 2 presents the answers concerning the knowledge of respondents on Standard Precautions.

Majority of the respondents $(\mathrm{n}=51,91.1 \%)$ agreed that invasive procedures increase the risk of nosocomial infection, while $89.7 \%(n=52)$ believed that the 
environment is the major source of bacteria responsible for nosocomial infection. As to the knowledge of the goals of standard precautions, all of the respondents ( $\mathrm{n}$ $=58,100 \%$ ) knew that the ultimate goal of the standard precautions is to protect both health care workers and patients from transmission of infection, while $84.5 \%$ $(n=49)$ thought that it is applied for all patients. Only 8.6\% $(n=5)$ believed that standard precaution is intended to protect only the patients from infection. With regards to knowledge on hand hygiene, $96.6 \%$ confirmed that hand hygiene is recommended before and after contact with a patient, while half of the respondents $(n=29,50 \%)$ reported that it is recommended before or after contact with a patient. All of the respondents $(n=58,100 \%)$ agreed with the use of gloves when there is a risk of contact with blood or body fluids, while $89.7 \%(n=52)$ think that gloves should be used for all procedures. Finally, almost all of the respondents $(n=57,98.3 \%)$ knew that when there is a risk of splashes or spray of blood and body fluids, the health care workers must wear mask, goggles, and gown.

Table 2: Responses to Questions Regarding Knowledge on Standard Precautions

\begin{tabular}{|c|c|c|c|}
\hline Statements & $\begin{array}{l}\text { Correct } \\
\text { Answer }\end{array}$ & Frequency & Percentage \\
\hline \multicolumn{4}{|c|}{ 1. Nosocomial infection... } \\
\hline $\begin{array}{l}\text { a. The environment (air, water, inert } \\
\text { surfaces) is the major source of bacteria } \\
\text { responsible for nosocomial infection. }\end{array}$ & No & 6 & 10.34 \\
\hline $\begin{array}{lllll}\text { b. Advanced age or very young age } & \text { or } \\
\text { increases the risk of } & \text { nosocomial } \\
\text { infection. } & & & & \\
\end{array}$ & Yes & 47 & 81.03 \\
\hline $\begin{array}{l}\text { c. Invasive procedures increase the risk of } \\
\text { nosocomial infection. }\end{array}$ & Yes & 51 & 91.07 \\
\hline \multicolumn{4}{|c|}{ 2. Precaution standards... } \\
\hline $\begin{array}{l}\text { a. Include the recommendations to protect } \\
\text { only the patients. }\end{array}$ & No & 53 & 91.38 \\
\hline $\begin{array}{l}\text { b. Include the recommendations to protect } \\
\text { the patients and the healthcare workers. }\end{array}$ & Yes & 58 & 100 \\
\hline c. Apply for all the patients. & Yes & 49 & 84.48 \\
\hline $\begin{array}{l}\text { d. Apply for only healthcare workers who } \\
\text { have contact with body fluid. }\end{array}$ & No & 45 & 77.58 \\
\hline \multicolumn{4}{|c|}{ 3. When is hand hygiene recommended? } \\
\hline $\begin{array}{l}\text { a. Before or after a contact with (or care of) } \\
\text { a patient. }\end{array}$ & No & 29 & 50 \\
\hline $\begin{array}{l}\text { b. Before and after a contact with (or care } \\
\text { of) a patient. }\end{array}$ & Yes & 56 & 96.55 \\
\hline c. Between patient contacts. & Yes & 37 & 63.79 \\
\hline d. After the removal of gloves. & Yes & 49 & 84.48 \\
\hline \multicolumn{4}{|c|}{ 4. The standard precautions recommend use of gloves. } \\
\hline a. For each procedure. & No & 6 & 10.34 \\
\hline
\end{tabular}




\begin{tabular}{|l|c|c|c|}
\hline $\begin{array}{l}\text { b. When there is a risk of contact with the } \\
\text { blood or body fluid. }\end{array}$ & Yes & 58 & 100 \\
\hline c. When there is a risk of a cut. & Yes & 57 & 98.27 \\
\hline $\begin{array}{l}\text { d. When healthcare workers have a } \\
\text { cutaneous lesion. }\end{array}$ & Yes & 54 & 93.10 \\
\hline $\begin{array}{l}\text { 5. When there is a risk of splashes or spray of blood and body fluids, the healthcare } \\
\text { workers must wear. }\end{array}$ \\
\hline $\begin{array}{l}\text { a. Only mask. } \\
\text { b. Only eye protection. }\end{array}$ & No & 54 & 93.10 \\
\hline c. Only a gown. & No & 55 & 96.55 \\
\hline d. Mask, goggles, and gown. & Yes & 57 & 98.27 \\
\hline
\end{tabular}

Table 3 presents the cumulative scores of the respondents on the questionnaires on standard precautions. Nearly half $(46.6 \%)$ of the respondents scored within the score range of 12 to 15 which is interpreted as "Good Knowledge", while $43.1 \%$ scored within the score range of 16 to 19 which is interpreted as "Very Good Knowledge". In general, student nurses possess "Good Knowledge" on standard precautions with a weighted mean score of 14.45

Table 3. Knowledge of Student Nurses on Standard Precautions

\begin{tabular}{|c|c|c|}
\hline Score Range & Frequency $(\mathrm{n}=58)$ & Percentage $(\%)$ \\
\hline $16-19$ & 25 & 43.10 \\
\hline $12-15$ & 27 & 46.55 \\
\hline $8-11$ & 5 & 8.62 \\
\hline $0-7$ & 1 & 1.72 \\
\hline Average Score & 14.45 & \\
\hline
\end{tabular}

Table 4 depicts the information obtained from respondents regarding their compliance activities.

As reflected on the table below, majority of the respondents $(n=54,93.1 \%)$ washes hand immediately after contacting any blood, body fluid, secretion, excretion and dirty substances, and more than half washes hands when comes in contact with different patients and after taking of gloves with $65.5 \%$ an d $56.9 \%$ respectively.

As to wearing of gloves, vast majority of the respondents wears gloves when disposing stool and urine $(n=47,81.0 \%)$, when handling patient's mucosa $(n=54$, 93.1\%), saliva and sputum culture $(\mathrm{n}=53,91.4 \%)$, and when comes in contact with blood $(n=55,94.8 \%)$. However, lower degree of compliance $(12.1 \%$, seldom; $17.2 \%$, never) were noted on wearing of gloves when performing parenteral injection of medications.

Majority of the respondents adheres to wearing of mask and protective suit or gown when performing procedures that might induce spraying of blood, body fluid, secretions and excretions with compliance rates of $94.8 \%(n=55)$ and $93.1 \%$ 
$(n=54)$, however, a significant percentage of non compliance $(n=11,18.9 \%)$ with the use of protective eye patch and eye goggles were noted.

As to proper care of used needles, $82.8 \%(\mathrm{n}=48)$ disposes needles and blades in a sharp disposal box or receptacle after using, and almost three fourths $(n=43$, 74.14\%) do not recap syringe after using.

In general, student nurses have a "High Compliance" of standard precautions with a grand mean of 3.59 .

Table 5 shows the components of standard precautions. When items were grouped into the 6 components, a mean for all items in each component was calculated for each respondent. The overall means were then calculated on the basis of the respondents mean scores for each item. Data indicated that the use of mask has the highest degree of compliance with a weighted mean of 3.95 which is interpreted as "High Compliance". On the other hand, the use of eye goggles has the lowest degree of compliance with a weighted mean of 3.19 which is interpreted as "Average Compliance".

Table 4. Compliance with Standard Precautions

\begin{tabular}{|c|c|c|c|c|c|c|}
\hline \multirow[b]{2}{*}{ Compliance Activity } & \multicolumn{6}{|c|}{ Degree of Compliance } \\
\hline & $\begin{array}{l}\text { Always } \\
\text { (n)\% }\end{array}$ & $\begin{array}{l}\text { Usually } \\
\text { (n)\% }\end{array}$ & $\begin{array}{l}\text { Someti } \\
\text { mes } \\
(\mathrm{n}) \%\end{array}$ & $\begin{array}{l}\text { Seldom } \\
\text { (n) } \%\end{array}$ & $\begin{array}{l}\text { Never } \\
\text { (n)\% }\end{array}$ & WM \\
\hline $\begin{array}{l}\text { Washes hands when comes } \\
\text { in contact with different } \\
\text { patients. }\end{array}$ & $\begin{array}{l}(38) \\
65.52\end{array}$ & (7) 12.07 & (2)3.45 & (7) 12.07 & (4) 6.90 & 3.17 \\
\hline $\begin{array}{c}\text { Washes hands after taking } \\
\text { off the gloves. }\end{array}$ & (33)56.89 & (17)29.31 & (6) 10.34 & (1) 1.72 & (1) 1.72 & 3.38 \\
\hline $\begin{array}{l}\text { Washes hands immediately } \\
\text { after contacting any blood, } \\
\text { body fluid, secretion, } \\
\text { excretion and dirty } \\
\text { substances. }\end{array}$ & (54)93.10 & (4)6.89 & $(0) 0$ & $(0) 0$ & $(0) 0$ & 3.93 \\
\hline $\begin{array}{c}\text { Wears gloves when } \\
\text { drawing blood samples. }\end{array}$ & (38) 65.52 & (12)20.69 & (1) 1.72 & (1) 1.72 & (4) 6.90 & 3.29 \\
\hline $\begin{array}{c}\text { Wears gloves when } \\
\text { disposing stool and urine. }\end{array}$ & (47)81.03 & (4)6.90 & (3)5.17 & (2)3.45 & (2)3.45 & 3.59 \\
\hline $\begin{array}{l}\text { Wears gloves when } \\
\text { handling impaired patient } \\
\text { skin. }\end{array}$ & (39) 67.24 & (9)15.52 & (7) 12.07 & (3)5.17 & $(0) 0$ & 3.45 \\
\hline $\begin{array}{c}\text { Wears gloves when } \\
\text { handling patients' mucosa. }\end{array}$ & (54)93.10 & (1) 1.72 & (3)5.17 & $(0) 0$ & $(0) 0$ & 3.88 \\
\hline
\end{tabular}




\begin{tabular}{|c|c|c|c|c|c|c|}
\hline $\begin{array}{l}\text { Wears gloves when } \\
\text { handling saliva or sputum } \\
\text { culture. }\end{array}$ & (53)91.38 & $3(5.17)$ & (2)3.45 & (0)0 & (0)0 & 3.88 \\
\hline $\begin{array}{c}\text { Wears gloves when } \\
\text { performing parenteral } \\
\text { injection of medications. }\end{array}$ & (19)32.76 & (17)29.31 & (5) 8.62 & (7) 12.07 & (10)17.24 & 2.48 \\
\hline $\begin{array}{l}\text { Wears gloves when } \\
\text { dressing wounds. }\end{array}$ & (33)56.90 & (13)22.41 & (8)13.79 & (1) 1.72 & (3)5.17 & 3.24 \\
\hline $\begin{array}{l}\text { Wears gloves when } \\
\text { cleaning blood trace. }\end{array}$ & (39)67.24 & (16)27.59 & (0)0 & (3)5.17 & (0)0 & 3.57 \\
\hline $\begin{array}{l}\text { Wears gloves when comes } \\
\text { in contact with blood. }\end{array}$ & (55)94.83 & (3)5.17 & (0)0 & (0)0 & (0)0 & 3.95 \\
\hline $\begin{array}{l}\text { Wears mask when } \\
\text { performing } \\
\text { operations/procedures that } \\
\text { might induce spraying of } \\
\text { blood, body fluid, } \\
\text { secretions and excretions. }\end{array}$ & (55)94.83 & (3)5.17 & (0)0 & (0)0 & (0)0 & 3.95 \\
\hline $\begin{array}{l}\text { Wears protective eye patch } \\
\text { or goggle when performing } \\
\text { operations/procedures that } \\
\text { might induce spraying of } \\
\text { blood, body fluid, } \\
\text { secretions and excretions. }\end{array}$ & (44)75.86 & (3)5.17 & (0)0 & $(0) 0$ & (11) 18.96 & 3.19 \\
\hline $\begin{array}{l}\text { Wears protective suit or } \\
\text { gown when performing } \\
\text { operations/procedures that } \\
\text { might induce spraying of } \\
\text { blood, body fluid, } \\
\text { secretions and excretions. }\end{array}$ & (54)93.10 & (4)6.90 & (0)0 & (0)0 & (0)0 & 3.93 \\
\hline $\begin{array}{c}\text { Do not recap syringe after } \\
\text { using. }\end{array}$ & (43)74.14 & (5)8.62 & (6) 10.34 & (1) 1.72 & (3)5.17 & 3.45 \\
\hline $\begin{array}{c}\text { Disposes needles and } \\
\text { blades in a sharp disposal } \\
\text { box or receptacle after } \\
\text { using. }\end{array}$ & (48)82.76 & (5)8.62 & (3) 5.17 & (1) 1.72 & (1)1.72 & 3.69 \\
\hline
\end{tabular}


Table 6 depicts the relationship between student nurses' knowledge and compliance of standard precautions. As seen gleaned on the table, the relationship between staff nurses' knowledge and compliance of standard precautions posted an r-value of 0.051 with a computed p-value of 0.386 which was lesser than its critical value of 2.00 at significance level of 0.05 .

Table 5: Summary of Compliance of Standard Precautions

\begin{tabular}{|c|c|c|}
\hline $\begin{array}{c}\text { Components of Standard } \\
\text { Precautions }\end{array}$ & Weighted Mean & Rank \\
\hline Hand washing & 3.49 & 4 \\
\hline Use of Gloves & 3.40 & 5 \\
\hline Use of Masks & 3.95 & 6 \\
\hline Use of Eye goggles & 3.19 & 2 \\
\hline Use of Protective Suit & 3.93 & 3 \\
\hline Proper disposal of used needles & 3.57 & \\
\hline Grand Mean & 3.59 & \\
\hline
\end{tabular}

Table 6: Correlation between Knowledge and Compliance of Standard Precautions

\begin{tabular}{|c|c|c|}
\hline Variables & r-value & p-value \\
\hline Knowledge and Compliance of Standard Precautions & 0.051449 & 0.386 \\
\hline
\end{tabular}

$*$ Significance level, $a=0.05 ;$ two-tailed; $d f=56$; critical value $=2.00$

\section{Discussions}

This investigation explored the knowledge and degree of compliance regarding standard precautions among nursing students in a government university in Samar, Philippines.

Findings indicated that student nurses were knowledgeable concerning standard precautions. Kim et al. also reported that knowledge of standard precautions was better among nursing students than among medical students [24]. This is in complete disagreement with that of Bamigboye and Adesanya study, where in only $46.2 \%$ of student nurses had very good knowledge [25]. Studies among nursing population also showed similar result to this study. Vaz et al. also reported that $90.0 \%$ of nurses had knowledge of standard precautions [26]. Good knowledge of standard precautions among student nurses may be due to inclusion of the concepts of standard precautions in the Philippine nursing curriculum. This result is worth noting since previous study conducted suggests that, one of the factors impacting compliance with the standard precautions in any hospital settings is sound knowledge on its concepts and principles [23]. Sax et al. reported that lack of knowledge is the major reason for non adherence to standard and isolation precautions [27]. However, result of this investigation disagrees with the 
other previous studies conducted among nurses and other clinicians regarding knowledge on aseptic technique and standard precautions in hospital settings. Melo et al. investigated nurses in one hospital in Goiania, Brazil, and found that only $75.6 \%$ understood the standard precautions as protective measures [28]. In the survey of Luo et al. of 1444 nurses, only half $(n=722)$ had knowledge of all the standard precautions [23], while Abdulraheem et al observed that half (50\%) of the health workers had no knowledge of universal precautions [29].

Results of this study also showed that knowledge about nosocomial infection was the lowest among the five components of standard precautions. Students did not know exactly what or who were the main sources of bacteria responsible for nosocomial infection since vast majority of them thought that the environment was the primary source of bacteria. This reinforces the need to intensify and strengthen teachings regarding standard precaution in classrooms.

As far as compliance with standard precautions is concerned, findings revealed that students had a high compliance. This may be due to stringent monitoring done by the faculty relative to standard precaution practices during clinical rotation. Furthermore, the student-faculty ratio during clinical could also attributed to such compliance. Due to limited number of students compared to number of faculty, they were able to monitor and follow up closely their student during the performance of standard precaution practices. This result is essential to note since failure to use and apply the standard precautions could be responsible for problematic and intractable infections [30]. This result however is not comparable with studies conducted by previous authors [23, 31].

Although majority of the students knew that mask, goggles and gown must be worn by the health workers when there is a risk of splashes or spray of blood and body fluids, surprisingly compliance with the use of protective eye patch or eye goggle was relatively low. This may be attributed to unavailability of personal protective equipments in every ward of the hospitals where they are rotated. This finding is similar with that of Luo et al. where they observed that the use of protective items such as eye shields, masks, and quarantine clothes among Chinese nurses had the lowest compliance [23]. Sadoh et al. also observed that less than two-thirds of health care workers used personal protective equipment such as aprons, gowns and gloves, during surgery and deliveries [32].

Central finding of this investigation was the lack of significant association between knowledge and compliance with standard precautions. This implies that knowledge on standard precautions do not necessarily affect compliance and application. This result is not supported by other authors. In the study conducted by Kim et al. it was revealed that knowledge is correlated to performance of universal precautions.[24] This result contradict the findings of other authors that firmly suggest that standard precautions knowledge was positively correlated with compliance, confirming that the greater the standard precautions knowledge the better the activity compliance [13-15, 23, 24,]. It is clear that knowledge alone may not be the determining factor for the compliance of the standard precaution practices. Furthermore, findings indicate that there is an existing dichotomy between theory and practice as suggested by many authors. 


\section{Conclusions}

It could be inferred from this investigation that the level of knowledge and compliance of standard precautions among the study population is rather high. However, teaching must be strengthened, particularly with respect to the concepts of nosocomial infection and hand hygiene where students scored less. Future educational strategies maybe enhanced through intensive return demonstration of effective use of protective equipments such as masks and eye goggles, requiring students to submit written journal, nursing care plans (NCP's) and anecdotal record of demonstration and integration of standard precaution practices during clinical exposure. Furthermore, nurse educators may need to provide an environment that models and promotes standard precaution practices by positive role modeling. Snow et al. reported that the hand hygiene practices of mentors influence the hand hygiene practices of students [33] and Feather et al.[11] underlined the importance of teachers modeling good clinical practices [34].

\section{Strengths and Weakness of the Study}

One of the strengths of this study is the inclusion of the entire population of the $3^{\text {rd }}$ and $4^{\text {th }}$ year student nurses in the university as respondents in the investigation. This ensures that there is no selection bias since respondents were not selected purposively. However, this investigation was conducted among student nurses from one university only, and the " $n$ " was small. Exclusion of student nurses from other university in other provinces may limit the generalizability of this investigation.

\section{Acknowledgement}

Investigators would like to thank all the participants for their time and effort in responding to the questionnaires.

\section{Conflict of Interest}

The authors declare that they have no competing interests.

\section{Author Contributions}

LJL, RAR, MMT, and were responsible for the design conceptualization, analyzing of data and drafting of the manuscript. MMT and RAR performed data collection and provided technical support. LJL provided the statistical expertise. 


\section{References}

[1] Twitchell, K. T. (2003). Bloodborne pathogens. What you need to know-Part II. AAOHN J, 51(2), 89-97.

[2] Kosgeroglu, N., Ayranci, U., Vardareli, E., \& Dincer, S. (2004). Occupational exposure to hepatitis infection among Turkish nurses: frequency of needle exposure, sharps injuries and vaccination. Epidemiol Infect, 132(1), 27-33. http://dx.doi.org/10.1017/S0950268803001407.

[3] Siegel, J. D., Rhinehart, E., Jackson, M., \& Chiarello, L. (2007). Healthcare Infection Control Practices Advisory Committee. Guideline for isolation precautions: preventing transmission of infectious agents in healthcare settings. Centers for Disease Control

[4] Widmer, A. F., Sax, H., \& Pittet, D. (1999) Infection control and hospital epidemiology outside the United States. Infect Control Hosp Epidemiol, 20, 17-21. http://dx.doi.org/10.1086/501546.

[5] Centers for Disease Control. (1988). Update: Universal Precautions for prevention of transmission of human immunodeficiency virus, hepatitis B virus, and other bloodborne pathogens in health-care settings. MMWR , 37, 377-388.

[6] www.cdc.gov

[7] Garner, J. S. (1996). Guideline for isolation precautions in hospitals. The Hospital Infection Control Practices Advisory Committee. Infect Control Hosp Epidemiol, 17, 53-80. http://dx.doi.org/10.1086/647190.

[8] Jawaid M, Iqbal M, Shahbaz S. (2009) Compliance with standard precautions: a long way ahead. Journal of Public Health, 38:85-8.

[9] Gammon, J., \& Morgen, H. (2007). A review of the evidence for suboptimal compliance of health care practitioners to infection control precautions. Journal of Clinical Nursing, 17, 157-167.

[10] Talan, D. A., \& Baraff, L. J. (1990). Effect of education on the use of universal precautions in a university hospital emergency department. Ann Emerg Med, 19, 1322-6. http://dx.doi.org/10.1016/S0196-0644(05)82295-4.

[11] Baraff, L. J., \& Talan, D. A. (1989). Compliance with universal precautions in a university hospital emergency department. Ann Emerg Med, 18, 654-7. http://dx.doi.org/10.1016/S0196-0644(89)80522-0.

[12] Gershon, R. R. M., Vlahov, D., Felknor, S. A., Vesley, D., Johnson, P. C., Delcios, G. L., \& Murphy, L. R. (1995). Compliance with universal precautions among health care workers at three regional hospitals. Am J Infection Control, 23(4), 225-36. http://dx.doi.org/10.1016/01966553(95)90067-5

[13] Taneja, J. (2009). Evaluation of knowledge and practice amongst nursing staff toward infection control measures in tertiary care hospital in India. The Canadian Journal of Infection Control, 24(2), 104-107.

[14] Vij, A., Williamson, S. N., \& Gupta, S. (2001). Knowledge and Practice of Staff towards Infection Control Measures in a Tertiary Care Hospital. Journal of Academy of Hospital Administration, 13, 31-35.

[15] Chan, M. F., Ho, A., \& Day, M. C. (2008). Investigating the knowledge, attitudes and practice patterns of operating room staff towards standard and 
transmission-based precautions: results of a cluster analysis. J Clin Nurs, 17, 1051-62. http://dx.doi.org/10.1111/j.1365-2702.2007.01998.x.

[16] Vaz1 K, McGrowder1 D, Alexander-Lindo R., Gordon L., Brown P, Irving R. (2010) Knowledge, Awareness and Compliance with Universal Precautions among Health Care Workers at the University Hospital of the West Indies, Jamaica.International Journal of Occupational and Environmental Medicine, 1(4): 171-181.

[17] Tait, A. R., Voepel-Lewis, T., Tuttle, D. B., \& Malviya, S. (2000). Compliance with standard guidelines for the occupational transmission of bloodborne and airborne pathogens: A survey of post anesthesia nursing practice. Journal of Continuing Education in Nursing, 31, 38-44.

[18] Sax, H., Perneger, T., Hugonnet, S., Herrault, P., Chraiti, M. N., \& Pittet, D. (2005). Knowledge of standard and isolation precautions in a large teaching hospital. Infect Control Hosp Epidemiol, 26(3), 298-304. http://dx.doi.org/10.1086/502543.

[19] Chan, R., Molassiotis, A., Chan, E., Chan, V., Ho, B., Lai, C.-Yiu, I. (2002). Nurse knowledge of and compliance with universal precaution in an acute care hospital. Int J Nurs Stud, 39, 157-163.

[20] Ofili, A. N., Asuzu, M. C., \& Okojie, O. H. (2003). Knowledge and practice of universal precaution amongst nurses in Central Hospital, Benin City, Edo State, Nigera. Niger Postgrad Med J., 10, 26-31.

[21] Oliveira, A. C., Marziale, M. H., Paiva, M. H., \& Lopes, A. C. (2009). Knowledge and attitude regarding standard precautions in a Brazilian public emergency service: a cross sectional study. Rev Esc Enferm USP, 43(2), 313-9.

[22] Tavolacci, M. P., Ladner, J., Bailly, L., Merle, V., Pitrou, I., \& Czernichow, P. (2008). Prevention of Nosocomial Infection and Standard Precautions: Knowledge and Source of Information among Healthcare Students. Infection Control and Hospital Epidemiology, 29(7), 642-647.

[23] Luo, Y., He, G-P., Zhou, J.-W., \& Luo, Y. (2010). Factors impacting compliance with standard precaution in nursing, china. International Journal of Infectious Diseases, 14(12), e1106-e1114. http://dx.doi.org/10.1016/j.ijid.2009.03.037.

[24] Kim, K. M., Kim, M. A., Chung, Y. S., \& Kim, N. C. (2001). Knowledge and performance of the universal precautions by nursing and medical students in Korea. Am J Infect Control, 29, 295-300. http://dx.doi.org/10.1067/mic.2001.114837.

[25] Bamigboye, A. P., \& Adesanya, A. T. (2006). Knowledge and Practice of Universal Precautions among Qualifying Medical and Nursing Students: A Case of Obafemi Awolowo University Teaching Hospitals Complex, ILEIFE. Research Journal of Medicine and Medical Sciences, 1(3), 112-116.

[26] Vaz, K., McGrowder, D., Crawford, T., Alexander-Lindo, R. L., \& Irving, R. (2010). Prevalence of injuries and reporting of accidents among Health Care Workers at the University Hospital of the West Indies. Int J Occup Med Environ Health, 23, 133-143. http://dx.doi.org/10.2478/v10001-010-0016-5

[27] Sax, H., Perneger, T., Hugonnet, S., Herrault, P., Chraiti, M. N., \& Pittet, D. (2005). Knowledge of standard and isolation precautions in a large teaching 
hospital. Infect Control Hosp Epidemiol, 26(3), 298-304. http://dx.doi.org/10.1086/502543

[28] MeloDde S, Silva e Souza AC, Tipple AF, das Neves ZC, Pereira MS. (2006) Nurses' understanding of standard precautions at a public hospital in Goiania - GO, Brazil. Rev Lat Am Enfermagem, 14:720-7.

[29] Abdulraheem, I. S., Amodu, M. O., Saka, M. J., Bolarinwa, O. A., \& Uthman, M. M. B. (2012). Knowledge, Awareness and Compliance with Standard Precautions among Health Workers in North Eastearn Nigeria. J Community Med Health Edu, 2, 131. http://dx.doi.org/10.4172/jcmhe.1000131

[30] Bree-Williams, F. J., \& Waterman, H. (1996) An examination of nurses' practices when performing aseptic techniques for wound dressings. J Adv Nurs, 23(1), 48-54. http://dx.doi.org/10.1111/j.1365-2648.1996.tb03134.x

[31] Parmeggiani, C., Abbate, R., Marinelli, P., \& Angelillo, I. F. (2010). Healthcare workers and health care-associated infections: knowledge, attitudes, and behavior in emergency departments in Italy. BMC Infect Dis., 10(1), 35. http://dx.doi.org/10.1186/1471-2334-10-35

[32] Sadoh, W. E., Fawole, A. O., Sadoh, A. E., Oladimeji, A. O., \& Sotiloye, O. S. (2006). Practice of universal precautions among healthcare workers. J Natl Med Assoc, 98, 722-726.

[33] Snow, M., White, G. L. Jr., Alder, S. C., \& Stanford, J. B. (2006). Mentor's hand hygiene practices influence student's hand hygiene rates. Am J Infect Control, 34, 8-24. http://dx.doi.org/10.1016/j.ajic.2005.05.009

[34] Feather, A., Stone, S. P., Wessier, A., Boursicot, K. A., \& Pratt, C. (2007). 'Now please wash your hands': the handwashing behaviour of final MBBS $\begin{array}{llll}\text { candidates. J Hosp } & \text { Infect, }\end{array}$ http://dx.doi.org/10.1053/jhin.1999.0705 